\title{
Interactive comment on "Case Study: Risk Analysis by Overtopping During an Upstream Landslide in Peñitas Dam, Mexico" by Humberto J. F. Marengo and Alvaro A. Aldama
}

\section{Humberto J. F. Marengo and Alvaro A. Aldama}

hmarengom@gmail.com

Received and published: 31 August 2019

\section{Dear Natasha:}

I have received Technical Corrections of Reviewer \#1 and here are my comments:

1. I have reviewed carefully each one of the comments of the reviewer and I have included them in the new document I am sending to you via pdf.

Printer-friendly version

2. I am working in the last point asked, which consists in write a short comparison of the methods such a general reader of NHESS can understand the language and the methodology stablished and be possible to generate a generic statement NHESS
Discussion paper

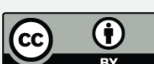


conclusion. I will finish on Tuesday September 2nd and then I will send it to you.

3. The main correction is that I have separated the mathematical approach and I am NHESSD including it in the Appendix I of the paper. I also send it. And I have written in the paper proper reference to it.

4. There are some technical observations made that I believe that are obvious in my opinion (discharge law of spillways for example). I am not changing, but if you consider it must be done; I will.

Please accept my apologies of files that I sent to you yesterday, they have not the corrections well done, like this I am sending to you now.

\section{Best regards.}

Humberto Marengo

Please also note the supplement to this comment:

https://www.nat-hazards-earth-syst-sci-discuss.net/nhess-2019-191/nhess-2019-191AC1-supplement.pdf

Interactive comment on Nat. Hazards Earth Syst. Sci. Discuss., https://doi.org/10.5194/nhess2019-191, 2019.

\section{Printer-friendly version}

Discussion paper 